\title{
Research on Chinese Electronic Book Retrieval in University Libraries
}

\author{
Jin Zhaohui \\ Library in Huazhong University of Science and Technology
}

\begin{abstract}
In the big data environment, the proportion of electronic book (e-book) collections in universities' libraries is getting higher and higher, and the number of readers of e-books in universities is rising. However, in the new situation, the retrieval of e-books, especially Chinese e-books, is challenged by salient problems. This paper finds the problems in the retrieval of Chinese e-books from collections, page setting, retrieval portal and others of Chinese e-books in several universities' libraries, actively seeks certain solutions to these problems, and proposes improvement measures. As such, Chinese e-books that is needed by readers can be quickly and accurately retrieved, the usage rate of Chinese e-books can be improved, and reader's satisfaction level can be maximized.
\end{abstract}

\section{Keywords-Chinese e-books; Retrieval}

\section{INTRODUCTION}

Thanks to the rapid development of information technology, the popularization of electronic resources, and the more electronic and digital library resources, collections of electronic documents see rapid growth, and the number of readers retrieving and using e-books is on the rise. This paper attempts to compare the e-book collections and the retrieval systems of libraries from Tsinghua University, Fudan University, Wuhan University and Huazhong University of Science and Technology in a bid to explore some problems in Chinese e-book retrieval and their solutions, so as to improve the accuracy and recall rate of e-books as much as possible.

\section{OVERVIEW OF LIBRARY'S E-BOOK COLLECTIONS}

E-books in Tsinghua University's library have become one of the library's main electronic resources. Tsinghua University's library collects 11 Chinese literature depositories and 12 foreign ones, and covers ancient books, medical books, and comprehensive books, etc., including Si Ku Quan Shu, Si $\mathrm{Bu}$ Cong Kan, the Twenty-Five Histories, Shi Tong, Chinese Historical Stone Inscriptions Compilation, Taiwan Literature Series, Superstar E-book, Scholar House E-book, Library \& Book E-book, China Yearbook Full-Text Database, Tsinghua University Teaching Information System, Encyclopedia Britannica Online, Ebrary E-book, Ecco E-book, Eebo Ebook, Springer E-book, Safari E-book, Net Library E-book, Ap Free E-book, Knovel four free chemical reference books, Scholarship Editions Free E-book, Siam E-book, Asia. com Free Foreign Language E-book, etc. [1].

Fudan University's library has 23 Chinese literature CLC number: G250.76 Document code: A. foreign ones, mainly covering biomedicine, teaching materials, teaching reference, ancient books, and comprehensive books, such as CALIS Teaching Reference Local System Full-Text Database, CALIS Chinese University Teaching Reference Book Full-Text Database, Superstar Digital Library, Diao Long Chinese Ancient Book Database, Western Medicine Book Database (People's Medical Publishing House), Pishu Database, Anatomy \& Physiology Online Anatomy And Physiology Textbook, BEP E-text, Brill Online Books, Cambridge Books Online, CRC-text, De Gruyter E-book, EBSCO-E-book Collection, Elsevier E-book-Mathematics, and Harvard University Press Archive E-books [2].

Wuhan University Library's e-books include 348 databases, in which there are 22 Western language e-book databases and 15 Chinese ones. The books cover education, law, hydropower, ancient books, special books, and comprehensive books, such as ACIS Humanities E-book - Selected Academic Works, Beck-Online German Law Database, Biographyin Context, Brill E-book, Business Expert Press (American Business Experts Press) E-book, CRC Press E-textbook, Early English Books Online, EBSCO E-book (formerly Net Library E-book), Eighteenth Century Collections Online, JSTOR E-journal and E-book, Muse E-book and E-journal, Springer E-journal and E-book, Wiley E-journals and E-book, World Bank E-library, Hein Online, Apabi E-book, CALIS Chinese University Teaching Reference Book Full-Text Database, Superstar Chinese E-book, full-text e-book of Twenty-Five Histories, My Library E-book, full-text e-book of $\mathrm{Si} \mathrm{Bu}$ Cong Kan, China Special Book Database (Wanfang), full-text e-book of Complete Library in Four Branches of Literature, Wuhan University Library CADAL Republic of China Collection, Wuhan University Library Western Language CADAL Classics Library, China's Several Ancient Books Library, China Digital Library E-book, and China Hydropower Engineering Featured Database, etc. [3]

Huazhong University of Science and Technology's electronic resources include 25 Western language e-books and 9 Chinese e-books, covering medical, engineering, computer science, and comprehensive books. Theelectronic resources include ACCESS series of reference book, ACS E-book, AMA Manual of Style Online Oxford Medical Handbook, AMS American Mathematical Society E-book, ASME E-book, Begell Hous E-book, CK Medical Platform, Ebrary E-book, Elsevier E-book, Emerald E-book, IEEE-Wiley E-book, IOP E-book, JSTOR E-book, Karger Medical Electronic Series, LWW Medicine E-book, My Library E-book, Oxford Scholarship Online Oxford Academic Monograph Online, 
Proques E-book, Safari E-book, SPIE E-book, Springer Ebook, Thieme E-book, Wiley E-book, World Scientific Ebook, Superstar E-book, Enzymology Method E-book Series, Chinese Online E-book, Shu Sheng E-Book Database, Peking University Founder Apabi Digital Book System, Diao Long Chinese Ancient Book Full-Text Database (Yongle Dadian Database and Ancient and Modern Book Integration Database), and Du Xiu Chinese Academic Retrieval [4].

Judged from the e-book collections of these universities, the Western language e-books published by several large publishers are relatively complete, but their focuses are different. Chinese e-books almost all contain books from Superstar E-book, Peking University Founder Apabi Digital Book System, Pishu Database, Diao Long Chinese Ancient Book Database and others. Combined with their discipline setting and key disciplines, they have respectively built an ebook database with the characteristics of their own. To a certain extent, the electronic resources have some overlap. Can all university libraries and even national libraries have an electronic library to share resources like a joint catalogue? In this process, however, it is inevitable to trigger the issue of copyright of electronic resources.

\section{Navigation Setting OF E-BOOKS IN THE WEB PAGES OF UNIVERSITY LIBRARIES}

The homepage of Tsinghua University's library shows that some e-books can be retrieved in the collection catalogue, and the retrieval of e-books and e-journals is specifically listed. At the same time, there is also a dedicated e-book navigation that allows access to proprietary databases.

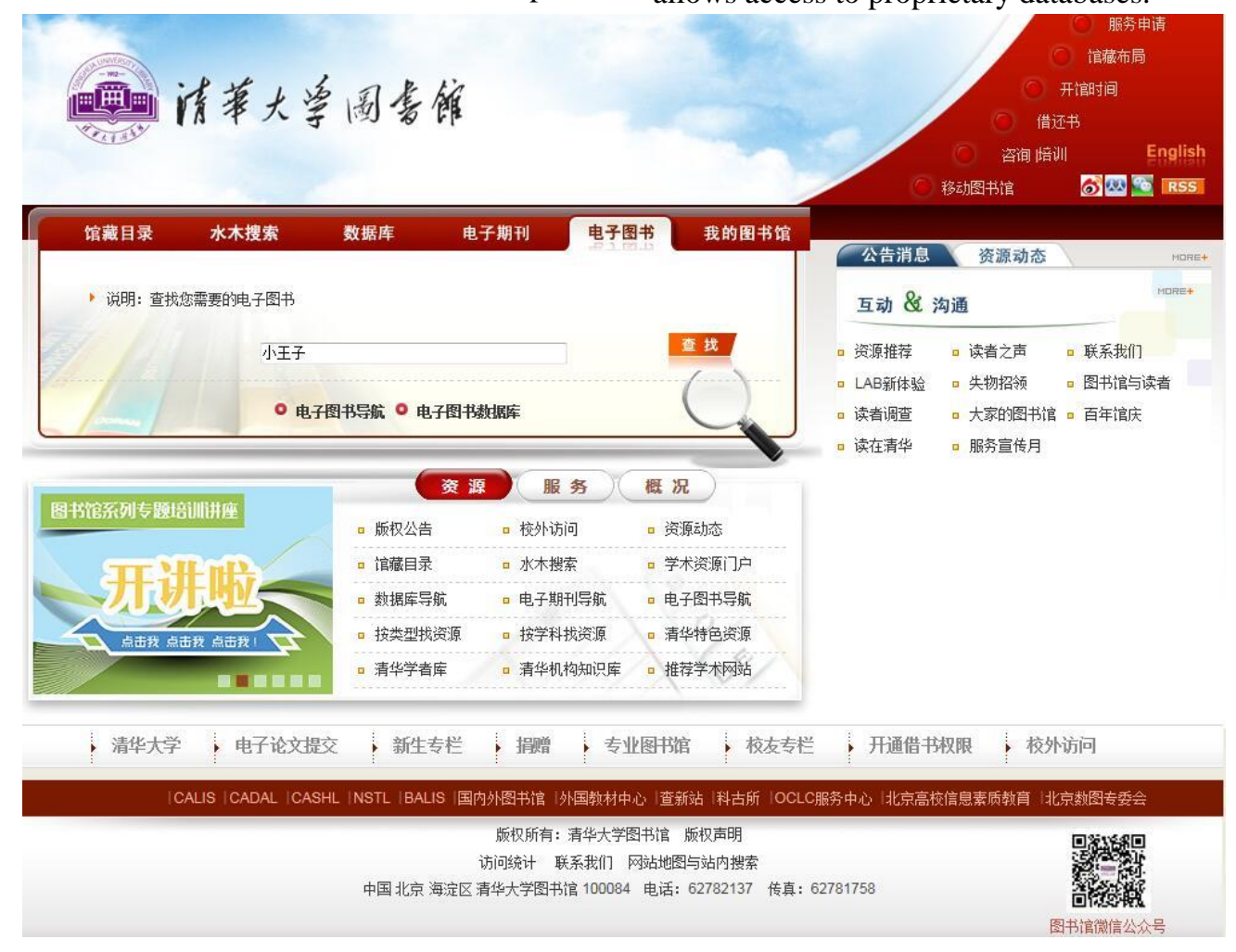

Fig. 1 The homepage of Tsinghua University's library

The homepage of Fudan University's library does not specifically list the e-book option. The "Search" option shows that readers can perform one-stop retrieval in paper and electronic resources. The "E-books" option is also listed under the "Resources" section on the right. 


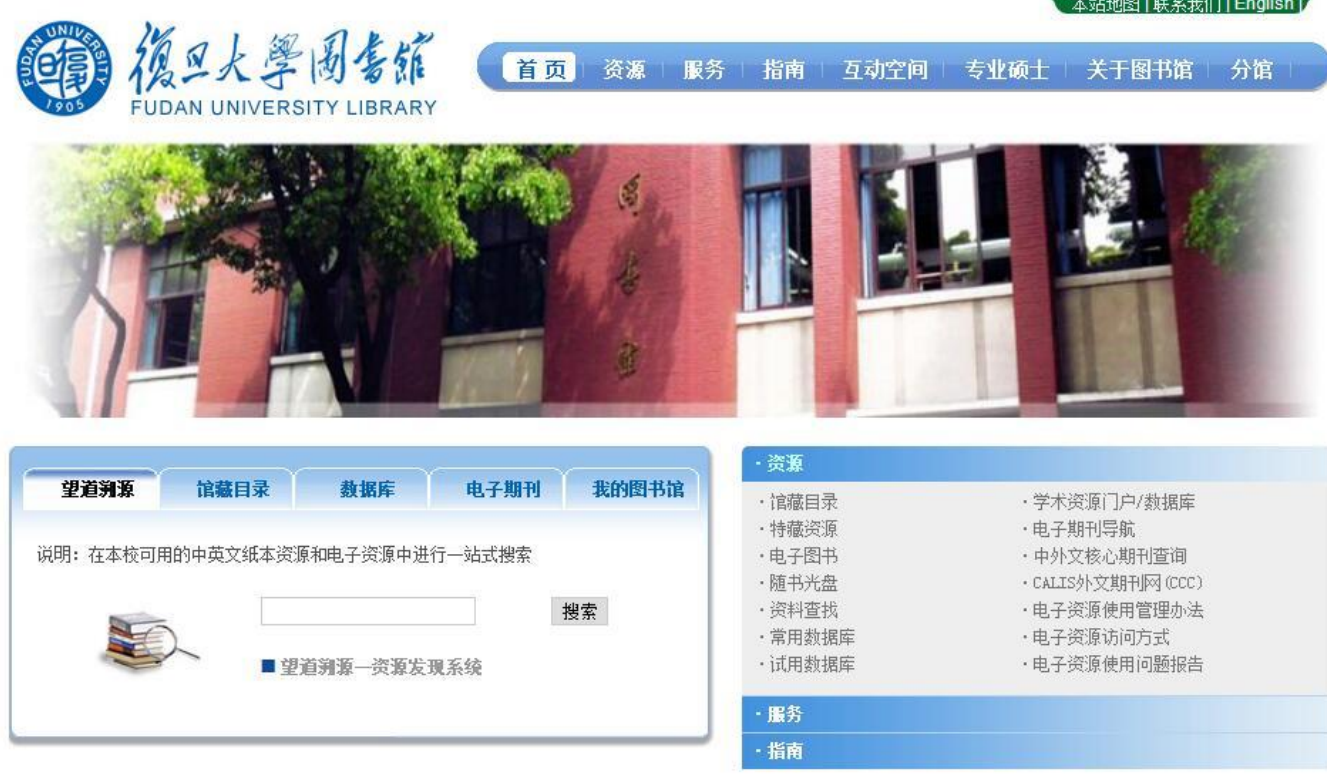

\begin{tabular}{|c|c|}
\hline 通然㕕告 资源动态 & \\
\hline - 逾期末还“已预约”图书读者名单 & 2018-04-27 \\
\hline - 医科图书馆参观进馆须知 HOT & 2018-04-18 \\
\hline 夏旦大学图书馆2018春季学期日常培训安排 & 2018-03-06 \\
\hline -图书馆关于 2018 年端午节放假的通知 nem & 2018-06-05 \\
\hline $\begin{array}{l}\text { ·'2018夏旦-木版水印版画艺术展”参展作品初访 } \\
\text { 入围通知 }\end{array}$ & $2018-05-25$ \\
\hline $\begin{array}{l}\text { - 人文社科数据研究所学术委员会2018年工作会 } \\
\text { 议召开 }\end{array}$ & $2018-05-22$ \\
\hline 奖书刊赏管 & 2018-05-03 \\
\hline 期刊数据库有奖问答 & 2018-04-28 \\
\hline
\end{tabular}

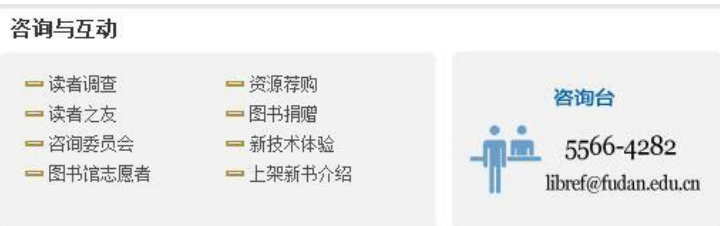

Fig. 2 The homepage of Fudan University's library

The homepage of Wuhan University's library provides an "E-books" column. When retrieving, readers can click "Retrieval" and automatically enter the retrieving page.

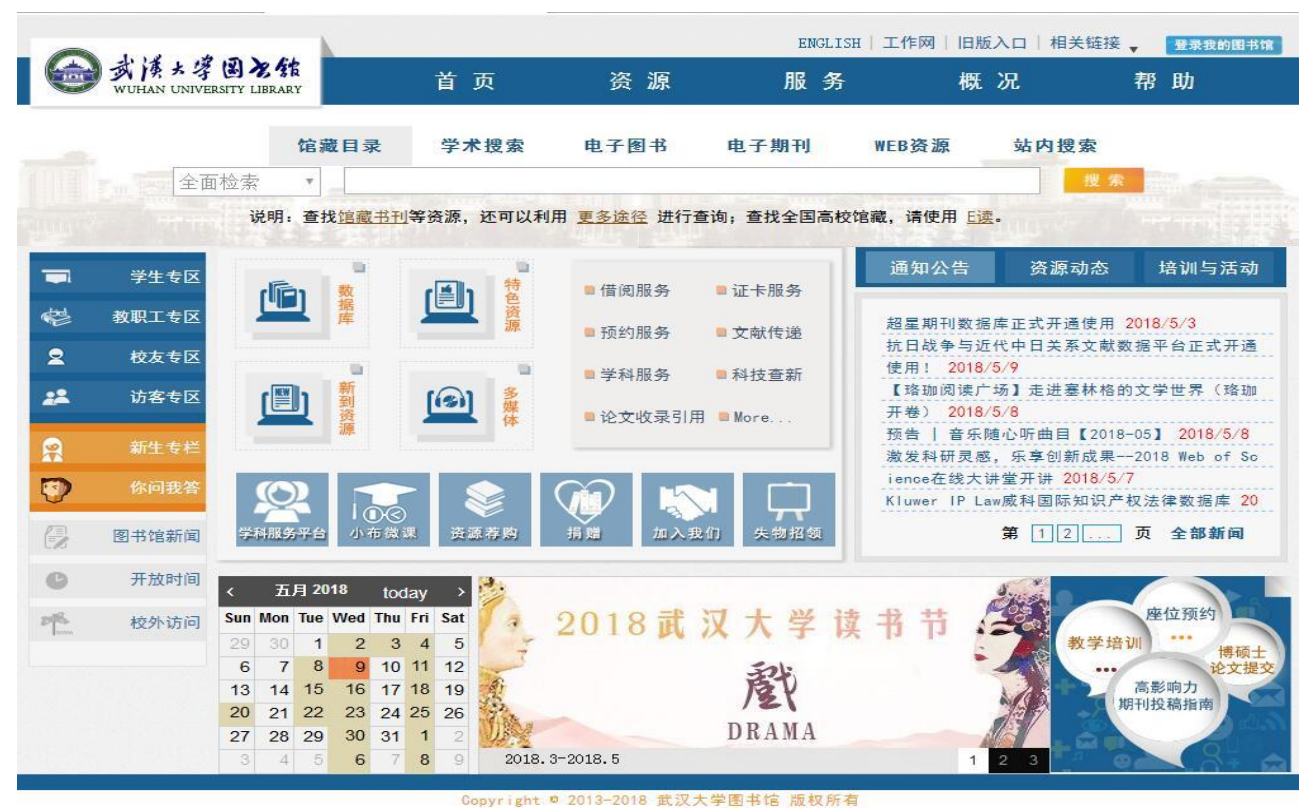

Fig. 3 The homepage of Wuhan University's library 
The homepage of Huazhong University of Science and Technology's' library does not have an e-book option. Readers need to enter "Electronic Resource Navigation" from
"Resource Display" to access e-books. After clicking "Electronic Resource Navigation", readers can see the retrieval page of each database.

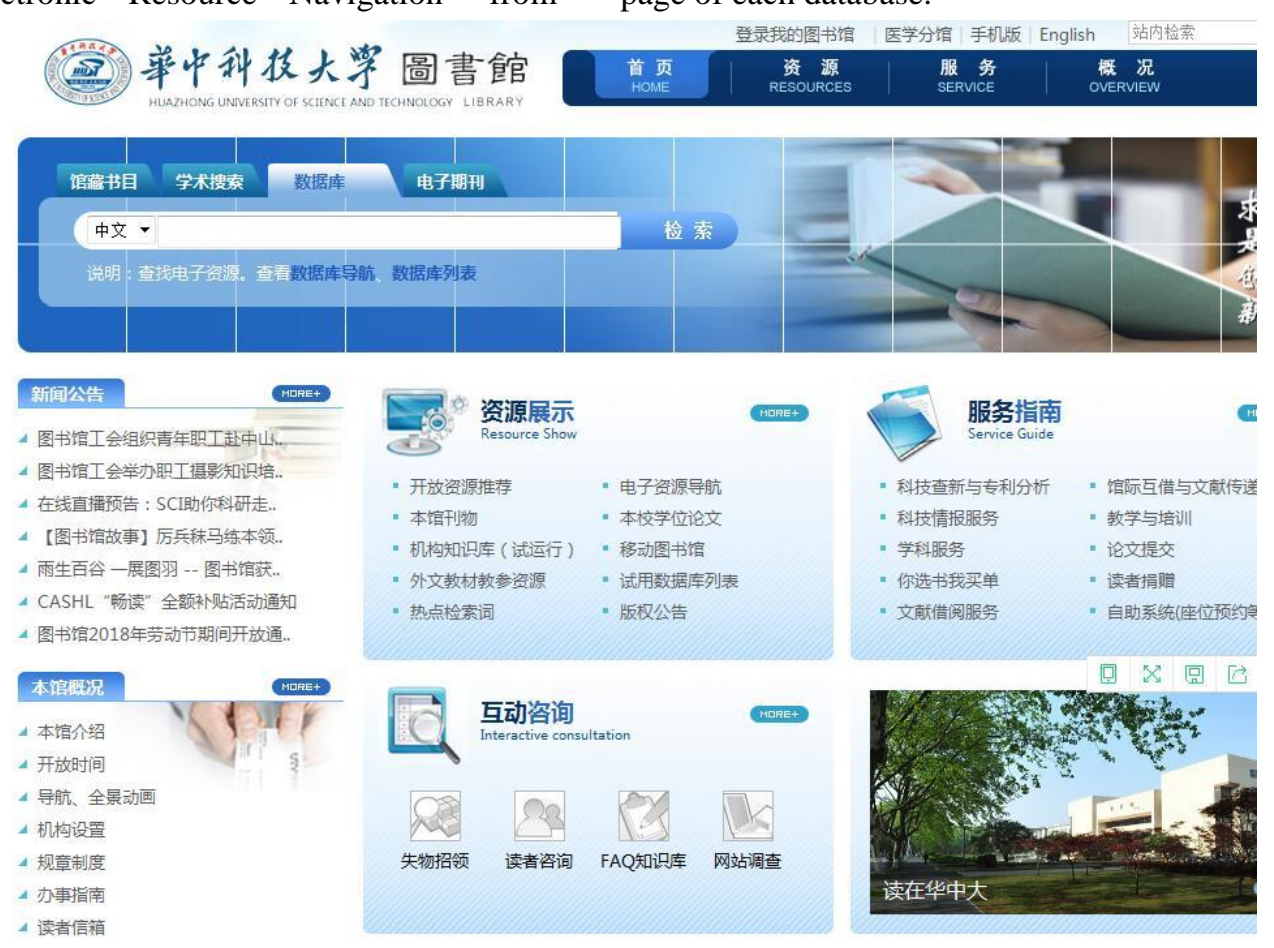

Fig. 4 The homepage of HUST's library

\begin{tabular}{|c|c|c|c|}
\hline \multicolumn{4}{|c|}{ 萧中科技大第圖書刢 } \\
\hline \multicolumn{4}{|l|}{ 中文数据库 外文数据库 试用数据库 } \\
\hline \multicolumn{4}{|l|}{ 分当前位置: 首页 $>>$ 数据库导航 $>$ 中文数据库 } \\
\hline 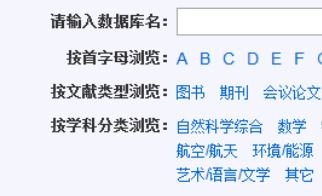 & $\begin{array}{l}\text { G H I J K L } \\
\text { 学位论文 专利 } \\
\text { 物理力学 化学化. } \\
\text { 地球料学天文学 }\end{array}$ & 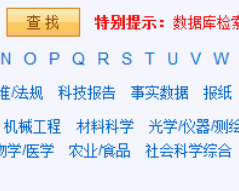 & 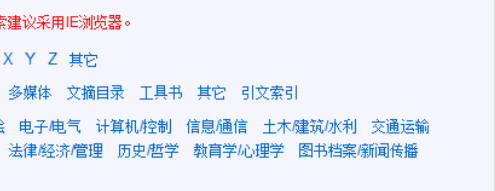 \\
\hline 数据库名 & 访河入口 & 资源类型 & 学料分类 \\
\hline airitilibrary台湾学术文献数据库 NEw & 点击登录 & 期刊, 学位论文 & 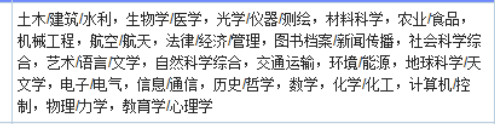 \\
\hline CIDP制造业数字资源平台 & 点击登录 & 图书, 事实数据, 多煤体, 其它 & 机械工程, 其它 \\
\hline $\begin{array}{l}\text { CNKI中国知网学术期刊全文数据库 (医药卫 } \\
\text { 生科技专辑) }\end{array}$ & 本地境像 & 期刊 & 生物学/医学 \\
\hline CNKI中国知网学术文献总库 & 点击登录 & $\begin{array}{l}\text { 期刊, 学位论文, 会议论文, 报, } \\
\text { 纸, 标准法规, 专利, 科技报告, } \\
\text { 事实数据, 文摘目录, 工具书 }\end{array}$ & 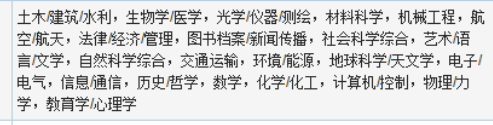 \\
\hline EPS全球统计数据/分析平台 & 点击登录 & 事实数据 & 法律经济管理 \\
\hline e读（免费资源） & 点击登录 & 文摘目录 & 社会科学综合, 自然科学综合 \\
\hline es线图情 & 点击登录 & 期刊, 科技报告, 事实数据 & 图书档案/新闻传播 \\
\hline INFOBANK高校财经数据库 & 点击登录 & 期刊, 报纸, 其它, 工具书 & 法律经济管理, 图书档案噺闻传播 \\
\hline KUKE数字音乐图书馆 & 点击登录 & 多媒体 & 艺术俉言文学 \\
\hline NoteExpress & 客户端下载 & 其它 & 其它 \\
\hline
\end{tabular}

Fig. 5 The homepage of HUST's library 


\section{PROBLEMS OF E-BOOK RETRIEVAL}

If readers click "Search" in Tsinghua University's homepage, they can find some e-books. For example, searching the title of Jean-Jacques Rousseau, 9 results are displayed, of which there are 4 online full-texts results, and click the book icon, a prompt appears, that is, check the specific borrow policy and allowed operations. There is a dedicated "E-books" option that allows readers to click and retrieve e-books directly. Perhaps because of visiting the page outside the campus, the corresponding search results could not be obtained.

In Fudan University's library, readers can retrieve e-books from the homepage "Resource Discovery System" of "Search". After I retrieved Jean-Jacques Rousseau, I obtained 38 results, including 29 full-text electronic resources which are available for viewing after clicking. If readers look up the text from other ways, they can click "E-books" in the page setup, and select "Database" to further search. Generally, these databases need to be logged in before being read further.

Electronic resource portal in Wuhan University's library (Metalib/SFX System) is the latest electronic resource service platform of Wuhan University's library. Readers can search for books directly on this platform via the title. For example, retrieving Little Prince, 13 results can be obtained. Perhaps due to a failure in the browser, the full text could not be got. Here is another example. Retrieving Jean-Jacques Rousseau from "E-books" on the homepage of Wuhan University's library, entering "Search" page, 9 results can be obtained, including a full text, which can be accessed directly by clicking the e-book.

A retrieval of collections from Huazhong University of Science and Technology's library shows that some e-books can be found. After entering the total inquiry system, retrieve Jean-Jacques Rousseau and obtain 16 results, including an electronic full text, and the rest are paper books of the library or books that can be obtained through document delivery. Retrieving Jean-Jacques Rousseau in the academic search, entering the Superstar discovery system, 138 related pieces of information can be obtained. Then the book is further researched under limited conditions. In the refinement search, choosing "E-books", 82 results can be obtained, including an e-book. The rest are related journal articles. The search takes almost 5 minutes, whose accuracy is poor. If readers retrieve from "Database Navigation", they must select an appropriate database and then further search, which is very inconvenient. Moreover, readers may have difficulty selecting a database.

From the above-mentioned OPAC retrievals of Chinese ebooks in several universities' libraries, the one-stop retrieval of e-books in each library can obtain some information, but the retrieval methods are not intuitive enough. Although some have special settings, the search effect is not ideal. Sometimes the retrieval for e-books is limited, but there are still many non-e-books, and even some documents related to the title have a worrying accuracy rate. From the reader's point of view, the retrieval of e-books is not very intuitive and convenient, and all one-stop retrieval shows that certain e-books are available. The Chinese e-books of Huazhong University of
Science and Technology are currently only catalogued by ebooks of Superstar Library, but MARC data of other Chinese e-books has not been completed yet. Therefore, in the collection retrieval of universities' libraries, the recall rate of e-books is challenged by some problems. The retrieval portals for e-books are not uniform, as some are called e-books, some are called e-resources, and some e-books appear in one-stop search.

\section{PROPOSED SOLUTIONS TO THE PROBLEMS}

MARC-based RDA, which is a RDA content standard designed for the resources description and retrieval for digital environments, with emphasis on helping users find, identify, select, and obtain the information they need; at the same time, it also supports clustering of bibliographic records, and shows the relationship between the work and its creators [6]. The standard is compatible with a variety of other criteria such as resource cataloging and retrieval, and is applicable to libraries, art galleries, archives, museums and other information facilities worldwide. It can better reveal the data characteristics of e-books and facilitate retrieval.

Some libraries do not have special bibliographic data for ebooks. They only add e-book link addresses to the corresponding paper bibliographic data. I prefer to establish a special e-book bibliographic system to build complete data, and participate in one-stop search of data. It is better for readers to search and use e-books.

To unify the search portal and standardize the search name, it's better than to set up a special e-book search portal, thereby simplifying the search steps and making the search more convenient and faster. The unified retrieval system can be used to retrieve the metadata, check and sort the results, and return the results intuitively to the reader, saving the reader's time and effort.

The database of different e-books generally requires the use of their own readers. The author wanders if e-readers can be unified, the status quo of e-book reading can be changed, and the use rate of e-books can be better improved. A unified and open e-book format is the trend of the times.

\section{CONCLUSION}

Information retrieval is essential to information resource utilization. In the electronic age, the popularity of e-books is an irresistible trend. How to actively provide readers with convenient, fast and accurate digital services in the world of information is a problem that every related professional worker should consider. This paper finds some problems in the e-book retrieval of universities through e-books collections of several universities' libraries, the e-book retrieval setting in the webpage, and the retrieval operation of e-books, such as the repetitive retrieval process, the inconsistent retrieval portal names, problems in recall rate and accuracy rate. The paper attempts to propose a uniform retrieval path through standardization and unification to solve the problem as much as possible. This paper hopes to provide better service to readers and improve their satisfaction level. Let us think in work and pursue improvement in thinking. 


\section{REFERENCES}

[1] Tsinghua University Library Homepage http://lib.tsinghua.edu.cn/dra/.

[2] Fudan University Library Homepage http://www.library.fudan.edu.cn/.

[3] Wuhan University Library Homepage http://www.lib.whu.edu.cn/web/default.asp.

[4] Huazhong University of Science and Technology Library Homepage http://www.lib.hust.edu.cn/.

[5] Long Xumei, Wang Ying, Liu Pengnian, Zhang Jianping. Management of Electric Books in Different Libraries According to their OPAC, Medical Library of Chinese PLA, 2011,30(03), pp.32-36.

[6] Zhao Ying, Li Hongjuan, Guo Huageng, Study on Chinese E-books Retrieval Based on the Contents. Journal of Intelligence, 2011, 30(10), pp.163-167+188.

[7] Jia Yanxia, Yang Hui. Revealing Chinese E-books via OPAC System: The Case Study of Chaoxing E-books Cataloging, Library Journal, 2011,30(03), pp.32-36.

[8] Wang Qingjuan. Research on Library Resource Integration Based on OPAC System Search Function, Research on Library Science, 2012(07), pp.69-72.

[9] Yu Xuqin, Chen Huilan. Cataloging of E-books and OPAC Disclosure. Journal of the China Society of Indexers, 2013,(3), pp.12-16.

[10] Yun Lin Hong, Jin Jie, Zhang Ning. Study on Innovation Strategy for Domestic Library Cataloguing Based on RDA. Journal of Library and Intelligence Sciences in Agriculture, 2014,26(04), pp.84-86. 